\title{
Collaborative design as a form of professional development
}

\author{
Joke Voogt $\cdot$ Therese Laferrière $\cdot$ Alain Breuleux $•$ \\ Rebecca C. Itow $\cdot$ Daniel T. Hickey $\cdot$ Susan McKenney
}

Received: 7 April 2014/Accepted: 22 December 2014/Published online: 18 January 2015

(C) The Author(s) 2015. This article is published with open access at Springerlink.com

\begin{abstract}
Increasingly, teacher involvement in collaborative design of curriculum is viewed as a form of professional development. However, the research base for this stance is limited. While it is assumed that the activities teachers undertake during collaborative design of curricular materials can be beneficial for teacher learning, only a few studies involving such efforts exist. Additionally many lack specific theoretical frameworks for robust investigation of teacher learning by design. The situative perspective articulated by Greeno et al. (1998) and third-generation activity theory as developed by Engeström (1987) constitute useful conceptual frameworks to describe and investigate teacher learning by collaborative design. In this contribution, three key features derived from these two theories, situatedness, agency and the cyclical nature of learning and change, are used to describe three cases of collaborative design in three different settings. Grounded on this
\end{abstract}

\author{
J. Voogt $(\bowtie)$ \\ University of Amsterdam \& Windesheim University, 15776, 1001 NG Amsterdam, The Netherlands \\ e-mail: j.m.voogt@uva.nl \\ T. Laferrière \\ Université Laval, 2325 Rue de l'Université, Quebec, QC G1V 0A6, Canada \\ e-mail: therese.laferriere@fse.ulaval.ca
}

\author{
A. Breuleux \\ McGill University, 845 Rue Sherbrooke Ouest, Montreal, QC H3A 0G4, Canada \\ e-mail: alain.breuleux@mcgill.ca \\ R. C. Itow · D. T. Hickey \\ Indiana University, 420 University Blvd., Indianapolis, IN 46202, USA \\ e-mail: rcitow@indiana.edu \\ D. T. Hickey \\ e-mail: dthickey@indiana.edu \\ S. McKenney \\ University of Twente \& Open University of the Netherlands, P.O. Box 217, 7500 AE Enschede, The \\ Netherlands \\ e-mail: susan.mckenney@ou.nl
}


theoretical basis and a synthesis of the three case descriptions, we propose an empirically and theoretically informed agenda for studying teacher learning by collaborative design.

Keywords Collaborative design $\cdot$ Teacher learning $\cdot$ Cases $\cdot$ Activity theory $\cdot$ Situated learning

\section{Introduction}

Drawing on Greeno et al. (1998) and Engeström (1987), this paper suggests that teacher professional development needs to be concerned with social aspects of learning, distributed across individuals and events, and directly meaningful to teachers' practice. Teacher learning, therefore, is not limited to formal professional development only, but takes place in all the arenas in which the teacher participates: the classroom, the community of (student-) teachers, and the school environment (Borko 2004). In Latour's (2008, pp. 3-7) terms, collaborative design deals with matters of concern. All things are considered, but it is an activity that is advantageously modest, attentive to details, interpretative, and normative. "It is never a process that begins from scratch: to design is always to redesign". In this paper, we situate teacher professional development in the context of teachers' involvement in educational change, be it through a national/state reform or a local reform, or through collaborative design of instruction or curricular materials, which they adapt to their context. Such involvement may be explicitly aimed to improve or change the teachers' instructional practice and at the same time develop a sense of ownership for the reform (Handelzalts 2009; Voogt et al. 2011). The assumption underlying this contribution is that the shared process of adaptation through collaborative design offers ample opportunities for teacher professional development.

In collaborative design, teachers create new or adapt existing curricular materials in teams to comply with the intentions of the curriculum designers and with the realities of their context. Often, external experts are involved in the process and provide the teams with up-to-date insights concerning the underlying rationale for the intended changes. The collaborative process of design provides opportunities for teachers to reflect on the intentions and implications of the reform. Teacher reflections stem from each team member's personal knowledge and beliefs, practice and goals for student learning (Parke and Coble 1997; Schön 1983). The interaction with peers and experts may deepen and challenge the teachers' reflections (Borko 2004).

Designing curricula typically results in concrete artefacts-curricular materialsmeaning that teachers are not only exposed to a new practice, but actively work to shape it. The enactment of the developed curricular materials allows teachers to observe and to reflect upon the outcomes. In order for collaborative curricular design processes to have the potential to contribute to teacher learning, it must be well-scaffolded (Borko 2004; Voogt et al. 2011). In addition, the curricular materials resulting from the process must be (a) based on up-to-date knowledge of good practice, and (b) considered by teachers to be usable in their contexts (Penuel et al. 2007; Clandinin and Connelly 1992).

Theories of learning and educational change offer useful conceptual frameworks to describe and investigate teacher learning by collaborative design. In particular, two perspectives reflect the empirical and theoretical dimensions of our work regarding teacher learning by collaborative design: (a) the situative perspective articulated by Greeno et al. 
(1998) and (b) third-generation activity theory as developed by Engeström and colleagues (1987; Miettinen 2013). Based on these two perspectives, we argue that three interrelated features are key to understanding learning by collaborative design in the teaching practice: the situatedness of activity, agency, and the cyclical nature of learning and educational change. We do not wish here to establish these three characteristics as evidence-based causal factors (e.g. Hattie's meta-analyses), but the nature of our research draws us to these commitments. However, at least two systematic reviews on continuing professional development (CPD) (Cordingley et al. 2003 and 2005) bear some similarities to our work and provide some evidence for the positive incidence of these features of professional development: the studies she conducted with her colleagues stressed that (1) sustained and collaborative CPD has a positive impact upon teachers' repertoire of teaching and learning strategies and their commitment to continuing learning and development; (2) there is evidence that collaborative studies improve pupils' learning and behaviour, and teacher practice, attitudes or beliefs. In addition, we do not refer here to a specific theory of "cyclical learning" but rather we emphasize how learning is cyclical in nature.

The next section briefly outlines the relevance of these perspectives to the study of teacher learning by collaborative design. This is followed by three cases from different contexts. Each case describes contributions to teacher learning relating to the aforementioned key elements: situatedness, agency and attention to the cyclical nature of teacher learning and educational change. Finally, the three case descriptions are synthesized, and we propose an empirically and theoretically informed agenda for further studying teacher learning by collaborative design.

\section{Theoretical underpinnings}

From the situated perspective, teachers benefit from learning when they are actively engaged in their own learning, willing to learn from each other and the learning takes place in contexts meaningful to them (e.g., Bransford et al. 1999; Greeno 1997). The distributed nature of knowledge and the value of learning communities are central to this stance, and also relevant to the work of teachers engaged in collaborative design. Given its "theoretical focus on interactive systems that are larger than the behavior and cognitive processes of an individual agent" (Greeno et al. 1998, pp. 5-6) the situative perspective, allows for the analysis of "intact activity systems" (p. 5) in which socially patterned practices situate individual cognition. Third-generation activity theory (Engeström 1987), also called cultural-historical activity theory (CHAT), offers a coherent treatment of the historical and cultural situation of teachers' activity systems in terms of motives, tools, communities, organizational responsibilities, and roles. Activity theory and related sociocultural perspectives are based on assumptions concerning the social nature of the human mind and on the inseparability of the human mind and activity (Kaptelinin 2005). In addition, CHAT is relevant not only for the analysis of existing teacher design activities, but also for its interventionist character shaping change (Sannino and Sutter 2011) through a process called "formative intervention" (for a thorough description of formative intervention see Virkkunen and Newnham 2013).

The situatedness of collaborative design

Within the situative perspective, teacher learning by collaborative design represents a trajectory from routine performance and problem-solving to emergent understandings. 
Newly encountered problems are acknowledged, and different interpretations are negotiated, leading to collective conceptual growth and learning practices (Greeno 2011). This process is very consistent with expansive learning (see also, the cyclical nature of learning and change, below) and formative interventions (cf. Engeström 1987). In teacher learning by collaborative design, teachers are agents of change, engaged in the creation of curricular activities and materials to improve student learning. As the teachers interact in their design communities, they share knowledge, exchange perspectives and tap into each other's expertise. These new experiences offer ample opportunities for learning, in part because they are so closely connected with everyday teaching realities and call on their abilities to solve the problems and challenges they face (cf. Putnam and Borko 2000).

Agency in collaborative design

Agency is an important concept in Vygotsky's theory (1987) of the developmental trajectory of human activity. Agency and change are understood as related. Individuals differ in their capacity to face change. Groups also vary as to how they address change. Bowles and Hattie (2013) distinguish three groups: stabilisers, who were low to moderate on factors of adaptive change; adaptors, who scored middle range on all of the adaptive change factors; and innovators, who were consistently high on eight factors of change (openness to opportunity, visualisation, planning, action, closure, social support, inner drive, and management of negative emotions). Engeström's activity theory framework (1987), which provides a basis for intervention in groups that are faced with change, puts forward the notion of "shared transformative agency". It is here applied to the conceptualization of the proactive activity of design work by teachers. The collaborative and socially-situated dimension in design work "requires and brings about collective and distributed agency" (Engeström and Sannino 2010, p. 7). In the case of collaborative design, the agency is transformative: a "future-oriented creative potential for generating intentional change in human activity" (Vanninen 2013). When designing collaboratively, teachers are enacting their capacity to initiate educational change. This active, agentive role on the part of the teachers, is consistent with literature on teacher professional development that suggests the active engagement of teachers over an extensive period (along with a focus on content, pedagogy and local context) as crucial for teacher learning (Fishman et al. 2013; Garet et al. 2001). By engaging teachers over an extended period in the collaborative design of curriculum materials, chances are increased that they will assume individual and collective responsibility, leading to intentional and transformative action and learning from the process.

The cyclical nature of learning and change in collaborative design

The learning and change processes taking place in teacher design activities are cyclical in nature. Engeström's (2006) model of "expansive learning" aptly captures the work of the collaborative designer: a sequence of epistemic actions going from questioning aspects of the existing practice, analyzing the situation, developing a new solution in a visible and transmittable medium, examining the new solution, experimenting with it to grasp its actual contour and possible limitations, implementing the solution with enrichments and conceptual extensions, and then reflecting on the process and consolidating it toward a stable form of new practice (Engeström and Sannino 2010). Each of these phases offers opportunities for learning. As Jonassen and Reeves (1996, p. 695) assert, “...the people 
who seem to learn the most from the systematic instructional design of instructional materials are the designers themselves."

Collaborative design in relation to: individuals, teams and systems

The manifestation of each characteristic (situatedness, agency and cycles) is dynamic. This changes based on the key elements of the professional development system. According to Borko (2004), key elements of any professional development system are: the program itself; the teachers participating; the facilitators; and the context. In reviewing the research on teacher professional development, Borko (2004) identifies three phases of research activities. The first phase involves single site programs, and studies that are typically focused on the program itself as well as individual teacher learning. The second phase involves the enactment of a professional development program in multiple sites, and research continues to investigate on program characteristics and teachers as learners, but also includes relationships among facilitators. In the third phase, context also receives attention, and all four elements are studied while the program is enacted at multiple sites. Thus, research on teacher learning through collaborative design can yield varied insights about situatedness, agency and cycles of learning and change. Building on the work of Borko (2004), this contribution reflects on existing investigations of each aspect (situatedness, agency and cycles) in relation to individuals, teams and systems.

\section{Methodological orientations}

The situative and activity theory perspectives are largely compatible and complementary in potentially very productive ways. Although agency, situatedness, and cyclical nature of learning and educational change can be studied from many perspectives, we notice that design-based (implementation) research (McKenney and Reeves 2012; Penuel et al. 2011) and formative interventions (Engeström 1987, 2011) are frequently the approaches of choice because they can inform design and scientific understanding at the same time. Both approaches are interventionist, iterative, process-oriented, utility-oriented, theory-oriented (cf. van den Akker et al. 2006). Design-based research is a genre of research in which the iterative development of solutions to practical and complex educational problems also provides a context for empirical investigation (McKenney and Reeves 2012). Design-based research takes place in real-world (as opposed to laboratory) settings, features collaboration between practitioners and researchers, give a voice to practitioners in the research team and engages them in the co-creation of new knowledge, which is a powerful process for promoting the uptake and use of new insights (Ormel et al. 2012). Both design-based (intervention) research and formative interventions emphasize the agency of collaborators in research (e.g. teachers, students and users of the social innovation). Hence, challenges and resistance are not left as problems of scalability; they enter into the very early processes. They also both give attention to analysing the existing situation, but the formative intervention method stresses the need to understand the histories of a situation that is the object of change. Further, the formative intervention method (Engeström 1987, 2011), contributes a structured set of terms and concepts to describe components of complex activity systems and their dynamic interactions (Engeström 2011). This method adds conceptualizations to handle more fully the societal dimension of educational change. 


\section{The three cases}

This section portrays learning through three features that are key to understanding learning by collaborative design in teaching practice: the situatedness of activity, agency, and the cyclical nature of learning and educational change. Three different cases are presented to demonstrate how these features were addressed in developing professional development scenarios and studying teacher learning through collaborative design in teams. The three cases are based on different theoretical perspectives, and each case represents one of the phases of research on teacher learning: a single site program; a well-specified professional development program enacted in different settings; multiple effective professional development programs (Borko 2004). The first two cases started from a situative perspective to teaching using design-based research as a methodological approach. The third case used design-based research, Activity Theory and formative intervention as the theoretical basis for the study. The three cases portray how situatedness, agency and the cyclical nature of learning and change manifest themselves in different ways. In the first and third cases, technology was a means to facilitate teacher learning. In the first and second cases, teachers designed technology-enhanced learning. Before describing the cases in depth, an overview of the cases as an advance organizer is presented in Table 1.

Case 1: USA: participatory professional development for personalized online learning

\section{Context}

In 2012, a working group at the USC Annenberg Innovation Lab convened to explore the sorts of professional development that might help educators enact "participatory" models of learning (Jenkins 2009). One of the outcomes of this workshop was an initial model of professional development (Hickey and Itow 2012) that was subsequently implemented and refined with several individual teachers in face-to-face and online settings. These implementations took place with eight teachers in a small Midwestern college town. Seven of these teachers taught face-to-face courses as well at large public high schools in and around the small Midwestern town. In order to distinguish this participatory approach from more "individualized" approaches to personalization, this model is tentatively characterized as participatory professional development for personalized learning. In 2013 Hickey and Itow were invited to use this new approach to redesign the English Language Arts (ELA) department of a small university-run online high school. This provided an ideal opportunity to explore whether the initial model of professional learning could indeed provide sufficient agency for collaboration between a group of teachers and a researcher to allow fundamental transformation. The existing classes were essentially "correspondence courses" where students downloaded assignments, completed them, and uploaded them for grading by the teacher. Five new teachers were hired with the express charge of collaboratively designing and then teaching four new ELA courses (one for each of the four secondary grades). The collaborative design took place over a 6 week virtual summer workshop led by the researchers.

The foregoing insights, coupled with a desire to create a scalable approach and respected real-world limitations, resulted in the following five online professional development principles: 


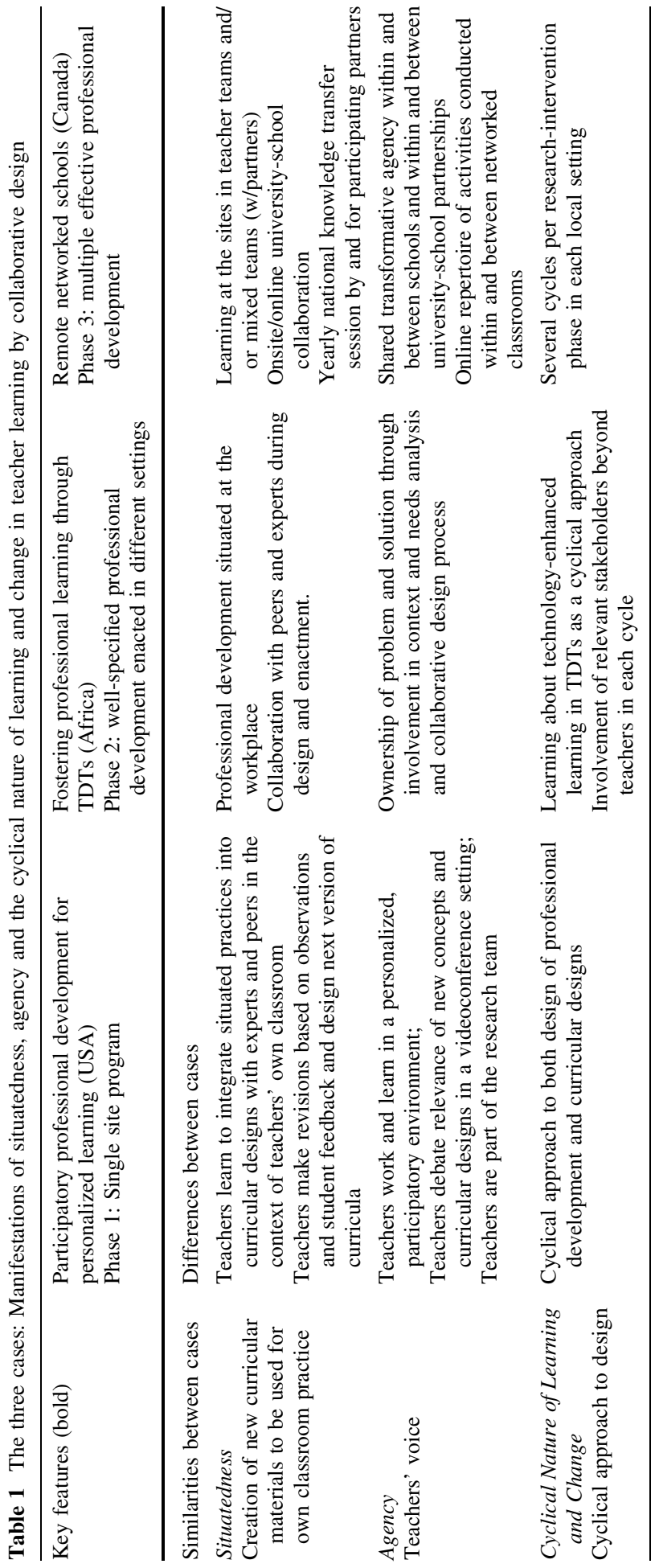


(a) allow teachers to work and learn within the kinds of learning environments and professional learning communities they are encouraged to create for their students, and provide support throughout the implementation process;

(b) teach teachers to design curricula that fosters connected learning (Ito et al. 2013) and productive disciplinary engagement (Engle and Conant 2002) while supporting conventional literacies, numeracies, and academic knowledge for which teachers are accountable;

(c) encourage teachers to reflect on their professional growth and practice without overwhelming teachers;

(d) accommodate prevailing levels of student network access with modest levels of professional development;

(e) make reasonable demands on teachers' time for designing and delivering curricula.

This work grew out of prior published work on situative approaches to student learning and is grounded pragmatically but resolutely in situated theories of cognition and learning. (e.g. Greeno et al. 1998). By situating professional development in the contexts of teachers' classes (whether physical or online), teachers can meaningfully participate in discussions that challenge their tacit assumptions about knowledge and stimulate reflective discourse.

\section{Situatedness}

Given that accountability pressure often functions to disempower teachers, this approach to professional development is intended to help teachers enact new participatory approaches to instruction while accommodating concerns over student and teacher accountability. It leverages the social aspects of online networks - such as discussion forums, wikis, and commenting - to foster a participatory environment. In this environment, teachers form a professional learning community that can be used for support as they grapple with new pedagogical practices and discuss how they might foster productive types of student engagement with disciplinary knowledge (Engle and Conant 2002) in their classrooms. The learning community is particularly concerned with fostering in their classrooms the same kind of participatory environment teachers experience during the professional development.

In this approach, both teacher learning and student learning are organized around a core participatory instructional routine. This routine manifested first in the professional development activities and then in the activities the teachers developed for their classes.

\section{Agency}

The five professional design principles introduced above were used to organize an online professional development workshop. The overall goal of the workshop was to help the teachers create new online courses that enacted the core participatory routine described above and related assessment practices. In particular, teachers were encouraged to focus their assessment and formative feedback for their students more directly on engaged social participation and less directly on apparent individual mastery.

The workshop structure had teachers work on parallel activities and then meet in thriceweekly videoconferences to review and discuss their efforts. Consistent with the first professional development principle, the workshop was initiated with teacher learning activities around the core instructional routine introduced above. This was effective in 
helping the teachers appreciate the central role of learner agency in participatory teaching. Giving the teachers agency to collectively negotiate how the participatory routines would be designed in their online classes presumably prepared them to then give their students agency to collectively negotiate how those routines would ultimately be enacted.

\section{Cyclical nature of learning and change}

This workshop represented the first formal pilot of the professional development model, though the model had been implemented and refined in small trials with select teachers prior to this study. The researchers initially guided the teachers through the curricular design process, stepping back as the teachers began to form a professional learning community. Throughout the workshop teachers were asked to reflect on their learning as they designed and implemented their curricula. The teachers' learning community served as a support system, allowing teacher-leaders to emerge. Fostering this learning community was a laborious but necessary step in refining the design principles for this approach to professional development, but it was less laborious than previous efforts (Itow and Hickey 2012).

The central goal in studying this collaboration was uncovering the issues teachers face when integrating new theories of learning into their teaching practice. This research was structured using design-based implementation research (DBIR) (Penuel et al. 2011) because it positions teachers as an integral part of the research team. The first of four elements of DBIR, focus on persistent problems of practice from multiple stakeholders' perspectives, emerged as a focal point of analysis. In this study, the persistent problem was defined by the research team as test-driven accountability pressures that threaten to narrow and decontextualize learning unless effective alternatives are provided. The openness of the professional learning community allowed this problem to be discussed and debated. When the teachers discussed the persistent problem, they primarily attributed the narrowed and decontextualized learning to pressure to enhance standards-based achievement on externally-developed achievement tests. This presented an opportunity for the researcher to point out the many broader practice-oriented standards in the new Common Core English standards and recognize the opportunity that they presented for organizing participation.

Because DBIR involves teachers directly in research, the use of this framework allowed for teachers to collaboratively explore new concepts, design learning environments, and aid one another in the learning process in an iterative and structured fashion. The DBIR framework facilitated collaborative inquiry amongst the entire research team, allowing for teachers' needs and experiences to influence immediate and future changes to the approach.

This approach to professional development grew out of a local, situative theory for learning and assessment for students. It continues to be refined as the research team uses teachers' insights and feedback about their experience with the model to make immediate adjustments to the current implementation while flagging issues to be addressed for the next iteration.

Just as participatory professional development has been refined in an iterative process, teachers were reminded to make adjustments to their designs based on their experience and feedback from their students. They were then encouraged to make formal refinements to their designs and prepare to implement them the next time they taught the course. 


\section{Key findings}

The most important finding is that this initial effort to begin scaling up this professional development model was ultimately successful. While they never met in person, the group soon built a community and found a routine. All four courses were successfully designed by the end of the summer. The remaining four teachers successfully implemented the four courses in the Fall 2013 and Spring 2014.

The extensive commenting and online discussions provided examples of collaborative agency and cyclical change beyond what was observed in the thrice-weekly videoconference. Across the six-week workshop, the teachers assumed more and more the responsibility for determining how the participatory learning and assessment activities could be enacted in these particular classes with the learning management system the school was using. In the first weeks, the researcher gave quite detailed feedback on all of the teachers' curricular designs and was contacted directly by each of the teachers when questions arose. Beginning in week two, however, and continuing to the end of the workshop, the teachers began to turn to each other for design advice, and one teacher in particular took on a leadership role. This teacher began offering suggestions and changes before such suggestions were requested; this allowed the researcher to step back and let the teachers help each other as they grappled with this new situated and participatory approach to learning and assessment.

Formal interviews were conducted with all of the teachers before, during, and after the implementation of the modules. While there was certainly a range of experiences, all confirmed that they experienced both individual and collective agency and that they felt prepared to make further refinements. For space reasons, the following examples are provided from one teacher who designed and then taught the 12th-grade class. In the first interview, she indicated that she was nervous because she was not yet comfortable working with technology. In the final interview, she gave specific examples of how she gave her students more agency of their learning.

I don't really think I was fully aware of how much I try to exercise all the control in the classroom or an online learning environment. I'm laying it all out there. ... And [I realized], oh my gosh, I front load all this too! And look how dense this is! And is this really all necessary? ... But it is hard to give up that control, giving students more freedom to evaluate their resources and talk about which ones are more useful and less useful and why.

This experience gave her agency in a professional learning community in the iterative refinement of the curricular activities:

As we've started this new semester together, I'm much more interested in asking meta kind of questions.

This teacher appeared to feel that the techniques she used in the professional development elicited insightful responses and deep thinking. Her experience was not an isolated one. All four teachers who taught courses shared similar stories about applying these techniques in their classrooms. As the courses the teachers developed were implemented and finished, the initial reaction from all of the teachers was one of excitement, as the students produced a wealth of writing and deep reflections.

All five designing teachers expressed that over the 6 weeks they gained a sense of agency in the community, which helped them gain a better understanding of how to integrate social practices, including networked writing, into their classroom practice. Each 
teacher reported continuing to use the concepts and skills they learned in the professional development. The teachers' experiences shaped the refinement of participatory professional development, and contributed to our understanding of how to provide participatory professional development for personalized learning that impacts student achievement and engages learners in networked writing.

2013 was an accreditation year, and the reviewing agency cited this work and the resulting interaction in the courses as a core reason for awarding the school a full 5 year accreditation. The school administration have requested that the researchers expand their effort expand both the professional development model and the participatory learning and assessment activities to other content domains at the school.

Case 2: Africa: fostering teacher professional learning in teacher design teams

\section{Context}

The three studies presented in this section took place in the frame of a research program (Pieters and Voogt 2008) that investigates relationships between sustainable curriculum innovation and collaborative design in teams of teachers, further addressed as teacher design teams (TDTs). The assumption underlying the program is that TDTs foster sustainable curriculum development and contribute to professional learning of participating teachers. The three studies reported here followed a design research approach (McKenney and Reeves 2012). In particular, the studies investigated how TDTs contributed to teacher professional learning in the context of curriculum reform. The three studies are part of a larger number of studies conducted in the frame of the research program and can be considered as an example of Borko's second phase, a well-specified professional development scenario enacted in different settings.

The first study (Anto 2013) took place in the context of a reform in Ethiopia to increase student-centered approaches to teaching and learning. The specific problem addressed was the need to increase the level of English language teaching in a remote Ethiopian University by introducing a communicative approach to language teaching using audio technology. The second study (Bakah 2011) took place in the context of a reform to upgrade Ghana's polytechnics to higher education institutions. The specific problem addressed was the professional development of lecturers in engineering with the aim to align the curriculum with needs of industries. The third study (Kafyulilo 2013) took place in the context of a reform aiming to integrate technology in secondary education in Tanzania. The focus of the study was on pre- and in-service teachers' development of technology integration competencies. Mixed methods designs were applied to collect data through questionnaires, individual and focus group interviews, and observation of TDTs interactions and classroom implementation of designed artefacts.

\section{Situatedness}

The TDTs were designed based on characteristics of effective professional development (e.g. Borko 2004; Penuel et al. 2007; Elmore and Burney 1999). The Ethiopian study was situated in a remote university, where the TDT of English language teachers started with a kick-off workshop to introduce and discuss the design task and the concept of collaborative design in teams. In Ethiopia, facilitators (experienced peers) and novice teachers collaboratively designed communicative English language lessons. The newly designed lessons were enacted, observed, and feedback was shared. In the Ghana study, TDTs were formed 
in the automobile, electrical and production engineering departments in two polytechnics. The TDTs prompted the teachers to bridge the gap between syllabus and industry competency standards, by creating situated learning experiences; this caused the teachers to restructure their syllabi to reflect current technology developments in industries. The Tanzanian study took place in a teacher education institute (pre-service teachers) and three secondary schools (in-service teachers). TDTs in physics, chemistry, and biology engaged in two cycles of technology-enhanced lesson design, enactment and reflection.

\section{Agency}

During all study phases, stakeholders, teachers in particular, substantially participated in setting directions for the study. The context and needs analysis phase aimed to involve stakeholders in problem definition. For example, Bakah et al. (2012a) reported the willingness of Ghanian polytechnic teachers to be involved in curriculum design in order to close the gap between the polytechnic curriculum and the needs of the local engineering industry. Polytechnics deans were also receptive to the TDT approach from the beginning. Ghanaian TDTs were in control of the goals, content and organization of the course while Tanzanian and Ethiopian TDTs were involved in determining the lessons comprising their design. The researchers organized the processes and facilitated the TDT activities. By the conclusion of the study, the collaborative design in teams had spread to other topics and departments in Ghana (Bakah et al. 2012b). In the Ethiopian setting the artefacts produced by the TDTs were distributed and used after the project formally concluded, but collaboration among English lecturers had not continued, due to lack of management support.

\section{Cyclical nature of learning and change}

Each study was conducted as four sub-studies: a context and needs analysis, two cycles of development, implementation and evaluation, and an impact study. The context and needs analysis resulted in a better definition of the problem and informed the development phase (e.g. Bakah et al. 2012a; Anto et al. 2012). In the impact study continuation of TDTs (e.g. Bakah et al. 2012b) or continued use of the acquired technology competencies were studied (Kafyulilo et al. 2013). The two cycles of development, implementation and evaluation aimed to improve the design and contributed to learning of all involved stakeholders. E.g. in the Ethiopian study, the parallel involvement of facilitators in regular teaching and training activities, and shortage of time were considered factors hindering teacher learning in the first cycle. The findings showed that novice teachers performed as well as facilitators. The Tanzanian study showed that supporting the collaboration process and facilitating the design process improved the quality of TDT work.

\section{Key findings}

The Interconnected Model of Professional Growth (IMPG) (Clarke and Hollingsworth 2002) was used to understand teachers' learning in each of the TDTs. The IMPG model postulates that change can take place in any of four domains: the external domain, the personal domain, the domain of practice and the domain of consequences. Change in the external domain is defined as becoming acquainted with new ideas, practices and/or strategies, introduced and developed by others. Change in the personal domain happens when teachers acquire new knowledge, skills, attitudes or beliefs. The domain of practice 
refers to change due to experiences during collaborative design in the TDTs and enactment of the new curriculum materials in educational practice. The domain of consequences deals with the outcomes of new practices for teachers and students. Change may occur in any domain and is mediated through the processes of reflection and enactment.

External domain The support offered to the teacher groups contributed to the changes found in all cases. The kick-off workshop served as an advance organizer for the design task. In the Tanzania study, teachers learned to conceptualize technology integration with the help of the TPACK (Technological Pedagogical Content Knowledge) framework (Koehler and Mishra 2008); in the Ghana study teachers obtained more knowledge on course design; while in the Ethiopian study teachers acquired a better understanding of communicative language teaching. Field trips (Ghana) gave a clear picture of the innovations in an industry that needed attention in the curriculum. Exemplary curriculum materials (Tanzania) or a teacher guide (Ethiopia) provided a picture of the products the teachers had to design. Expertise from domain experts during design and enactment helped teachers to develop the pedagogical content knowledge needed for the new approach to teaching technology-enhanced teaching (Tanzania) or communicative language teaching (Ethiopia).

Personal domain All three studies found increases in teachers' knowledge and skills (Bakah 2011; Anto 2013; Kafyulilo 2013). The studies in Ghana and Ethiopia also found changes in teachers' beliefs. The study in Ghana contributed to a commitment to quality curriculum materials and improved teacher collaboration. The Ethiopian study found changes in classroom teaching. In the Tanzanian study participation in TDTs had an impact on continued use of technology in teaching but that this also depended on the extent that technology was easy to use and to access and the support offered by the school management.

Domain of practice (collaborative design) Teacher interactions during the design process were explicitly studied in Ghana and Tanzania. In the Ghana study, the concrete, practical tasks brought teachers face to face with their subject matter. Additionally, teacher team discussions on the subject matter, delivery and outcomes enhanced interaction and knowledge sharing. The teachers' participation in design teams was enactment-driven. The Tanzanian study showed that teachers viewed the design team experience as a valuable learning opportunity, and that teachers also indicated they had developed technology integration knowledge and skills through their participation in design teams.

Domain of practice (enactment) Teachers use of the designed products was studied most extensively in Ghana and Tanzania. In the Ghana study, enactment was a crucial factor that contributed to professional growth. This was revealed in classroom practice and design teams through reflections. Reflections served as an intermediary factor to reinforce the acquired knowledge. Focus group discussion results from the Tanzania study showed that teachers developed technology integration knowledge and skills through their understanding of students' learning problems, through solving technological challenges that emerged in the classroom, and through students' feedback. Reflections on the implemented lessons led teachers to change their technology integration approaches.

Domain of consequence The Ghana study students were interested in the new lesson topics, which encouraged discussion. In the Ethiopian study, students reported changes in 
their communicative English skills. In the Tanzania study, teachers experienced an increase in students' interest in science, more active involvement of students, and a deeper understanding of science subjects.

The studies presented here confirm findings of studies from the developed world about teacher design teams as a means for continuous professional development (e.g. Voogt et al. 2011; Huizinga et al. 2014; Velthuis et al. 2014).

Case 3: Canada: teacher collaborative design of learning activities in Quebec's remote networked schools

\section{Context}

The Remote Networked School (RNS) initiative goes back to 2002. Small rural schools were under the threat of closure due the quality and access to education given the financial cost of maintaining minimal equality of opportunity for students. In response, the Ministry of Education mandated CEFRIO to act on its behalf in an exploration of how to enrich the learning environment of these schools by taking advantage of information and communication technologies. A systemic approach (Engeström 1987) was adopted by a tripartite partnership (Ministry of Education and CEFRIO/school districts/universities). The partnership structure created a multi-level change process: agents at all levels, from superintendents to teachers, as well as parents and community organizations, were informed and involved.

Teacher collaborative design was conceptualized as a collective activity involving key education partners. Classroom teachers' participation was considered essential to the codesign of the remote networked school. The RNS' research-intervention team wanted to apply five different perspectives: (1) The reflective practitioner model (e.g. Schön 1983), (2) Putnam and Borko's (2000) perspective on cognition, (3) sociocultural perspectives (e.g. Lave and Wenger 1991), (4) the works of designers of computer-supported collaborative learning environments (e.g. Barab et al. 2004 and Scardamalia and Bereiter 1994), and (5) knowledge building approaches (Bereiter and Scardamalia 1993). It was expected that teachers' professional development would benefit from this approach.

\section{Situatedness}

The two-year pilot study engaged three school districts and 12 schools (phase 1, 2002-2004). Teacher professional development was one key element that took different forms and shapes, including planned tutorials and improvised exchanges with members of the research-intervention team, collaborative design sessions (using collaborative technologies), researchers and teachers' presentations or demonstrations at local events and national knowledge transfer sessions. Teacher participation in the design process of their local remote networked school resulted in students from different classrooms engaging together in learning activities and projects as well as in collaborative inquiries. This meant that an alternative activity system had to develop for teachers to engage students in curricular activities that apparently went beyond what had been traditionally expected of them. In its early years, the initiative benefited from an educational reform that spanned the entire K-12 curriculum and emphasized both instructionist and constructivist pedagogical approaches. The expression mise en ceuvre de l'école éloignée en réseau meant iterative cycles of RNS design/creative implementation. Over 300 schools have already engaged in 
the RNS initiative. In the latter phases, institutionalization of the RNS has been the focus of the partnership.

\section{Agency}

The attention of the research-intervention team was on shared transformative agency. It means, for instance that it was not the individual performance or a teacher's development of generic design competencies that was attended to, but rather, the collective performance and the development of local competencies shared among a group of teachers. At the onset, the research-intervention team put forward the following four design principles:

- Ease of access Networked computers and online resources and tools need to be accessible without losing time once basic technical skills are mastered.

- Multi-modal human interactions Teachers and students meet face-to-face onsite/online. Teacher educators and teachers also meet onsite/online.

- Active collaborative learning Teachers' networked classrooms foster peer interaction in the pursuit of projects and inquiries.

- Collaborative knowledge building Collaborative technologies have affordances that support inquiry, meaning negotiation and idea improvement among colleagues and student peers.

From day one, the RNS initiative has recognized teachers' agency in the co-design of the RNS. Teachers voluntarily engaged in several types of collaborative design activities, and especially ones based on knowledge building principles. Planning, conduction and evaluation of activities were carried out using mediating tools such as collaborative technologies and socio-constructivist concepts, including the classroom-as-a-learningcommunity. Online support/guidance was provided in the form of: a research-intervention team member accessible all day through the videoconferencing system; and, in 2011, three teachers with extensive RNS experience joined the research-intervention team (four more joined in 2013) and they have been interacting one day a week since with colleague teachers. Teachers initially asked for technical support, but increasingly asked support in pedagogical design.

Teaching in different schools, the teachers collaborated mostly online in networked classrooms. The technology in use included a web-based videoconferencing system and a web-based platform for written online discourse, one on which design and learning/ knowledge building artefacts resided. Selected artefacts were later included in a book written in collaboration with teachers (Allaire and Lusignan 2011). Over 500 volunteer teachers have been active in the RNS initiative.

\section{The cyclical nature of learning and change}

The RNS initiative progressed through several iterations following a design-based research methodology (Inchauspé et al. 2004; Allaire et al. 2006; Laferrière et al. 2008). Research iterations were a key feature of the intervention. The research-intervention team provided ethnographic data for discussions with school districts, schools, and interested individual teachers feeding the refinements of following iterations. The data sources included questionnaires, interviews, and online artefacts (videoconference recordings, forum exchanges and websites, including guidelines, exemplary practices and written accounts).

The analysis mostly concentrated on three activity systems: The university-school partnership activity system, the classroom-based collaborative inquiry activity system, and 
an online collaborative space for learning and knowledge building activity system. Actions and operations enabling or constraining the use of collaborative technologies and knowledge building principles as mediating tools were pinpointed.

Learning/knowledge building in a distributed way became possible through a historically developing activity within each of the concrete settings. Iterations (or cycles of research-intervention) have been the cornerstone of the design-based research. Using Engeström's (1987) activity theory framework, teacher collaborative design became the overarching action within and between the RNS activity systems (Laferrière and Breuleux 2011).

\section{Key findings}

Three types of interconnected circumstances pertaining to each activity system and their related tensions, let alone their resolution, appear to be necessary for teacher collaborative design as well as for sustainable and scalable innovation in our local context:

- Strong university-school partnerships The research-intervention team interacted with school district and school leaders and personnel. Tensions arose, and had to be worked out. For instance, the decision to favor only two collaborative technologies, which meant providing technical support and data gathering/analysis only to these technologies, created tension in some school districts. The use of the same platform for verbal and/or written discourse was considered a baseline condition for capacity building. One platform was replaced by a web-videoconferencing system that made things easier for school district based technicians. The other platform, Knowledge Forum, grew in acceptance as evidence accumulated of its effectiveness for supporting networked classrooms' written discourse. Tensions are sources of innovation in university-school partnerships that can engage in productive dialogical relations. Our own study confirms previous findings such as those of Martin et al. (2011).

- Evolving collaborative inquiries Teachers learned from one another as they designed and led their classrooms into online learning activities and collaborative projects and inquiries. They had to agree on a learning activity/project to conduct, an investigation theme that was inclusive of questions and problems that each could align with the curriculum, a time schedule, and the like. Tensions that arose, for instance, related to school schedules had to be worked out. At first, teacher inquiries tended to focus on a specific activity using one collaborative technology. By their third year with the RNS initiative, most teachers are capable of combining classroom use of the two collaborative technologies for inquiring into sustainability issues with students and reflecting on the process with other participating teachers.

- Ownership of an online collaborative space The learning artefacts uploaded on Knowledge Forum became exemplars, demonstrating student capacity to inquire into driving questions. Teachers from one school had evidence to show when other teachers expressed doubts about the students' overall capacity to do so or the actual connection of such activity to the curriculum. For instance, the level of complexity of online writing processes was a source of tension that kept reappearing and had to be dealt with for teachers to refine their scaffolding of students' writings.

Teachers' work setting was transformed as the learning community expanded and formed a web of networks, that is, as small groups interacted and learning and/or knowledge-building artefacts were shared. The new open-ended workplaces became congruent with principles brought forward by sociocultural perspectives for understanding 
cognition and conducive with the informal learning that takes place in communities of practice (Barab et al. 2004) or professional learning communities (Vescio et al. 2008).

However, there were systemic limits to the expansion of teacher collaborative learning; ones reflective of powerful cultural schemes in place at the schools, characterized by conventional teaching and organizational management of large schools. One limit that restricted sustainability and scalability is inherent to the integral nature of co-design: organizational partnerships that create hubs of innovation, university-based and schoolbased participants working collaboratively to develop computer-supported pedagogical designs and delineate relevant research questions. Together but at too few sites, given the Quebec student population, teachers pushed the boundaries of their individual teaching and that of their collaborators as they encountered real and authentic new problems in their practices.

Despite these limitations, teacher collaborative design was the result of teachers' exercise of agency and leadership as manifested by boundary crossing, artefacts, stories, and new routines or rituals. Based on these results teacher collaborative design proved to be relevant, feasible, and sustainable.

\section{Synthesis}

In all three cases, situatedness was realized because teacher learning in teams was closely connected to the teachers' workplace (Africa, Canada) or focused on curricular designs to be implemented in one's classroom practice (USA, Africa). The involvement of different stakeholders from the start fostered sustainable implementation of a collaborative design process and the products resulting from the approach (Africa, Canada). Collaboration with experts (all three cases) yielded quality of the curricular artefacts that were designed and contributed to teacher learning of new approaches to teaching and learning (USA, Africa, Canada) and development of design expertise (Africa). Knowledge transfer sessions supported by technology (USA, Canada) fostered learning of participating teachers and contributed to scaling the reform (Canada). Agency was realized because teachers were actively involved in problem definition and solution (USA, Africa). In Canada, partnerships formed between schools and between schools and the university fostered ownership, and could not be realized and sustained without technology. Design-based research (USA, Africa, Canada) and the approach of formative intervention (Canada) gave all participants a voice in the design of the professional development arrangement. In all three cases, the interventions were shaped through iterative cycles of design.

\section{Toward an empirically and theoretically informed agenda for studying teacher learning by collaborative design}

Together, the three cases in this contribution represent Borko's (2004) phases of research of teacher professional development programs. Two of the three cases (USA, Africa) examined the effect of collaborative design on individual teacher learning with an emphasis on teachers' development of technology-enhanced learning. The cases in the USA and Canada used technology as a means to facilitate the collaborative design process. The Canadian case studied, in particular, system level impact of collaborative design processes, as it investigated partnerships between schools and between schools and the university. Although the three cases contributed to our understanding of collaborative 
design as a form of professional development, we also acknowledge that there are still many blind spots in understanding how collaborative design contributes to teacher learning. Based on the theoretical underpinnings and the case descriptions, we propose a research agenda to gain more in-depth insights in how collaborative design contributes to teacher learning. Like the studies presented here (and the summary in Table 1), the agenda emphasizes the three key features of teacher learning by collaborative design (situatedness, agency and a cyclic approach) throughout each phase of teacher professional development [individual teacher learning, team learning and system learning (Borko, 2004)].

Individual teacher learning in collaborative design

Research at the individual teacher level concerning situatedness, agency and the cyclical nature of learning and change deals with understanding factors affecting individual teachers' learning, when they participate in a collaborative design effort.

\section{Situatedness}

Our cases showed the importance of individual teacher learning through collaborative design in authentic and meaningful contexts. However, as the USA case showed, teachers can also feel restricted by the external conditions such contexts have. Several studies showed that to better understand teacher decision-making in collaborative design processes, external priorities set by other stakeholders (e.g., national/state policy, school principal, parents) and teachers' practical concerns (Doyle and Ponder 1978) need to be taken into account. How external priorities and practical concerns impact teacher learning through collaborative design requires further collaborative inquiry. The (small scale) study of Boschman et al. (2014) suggests that practical concerns dominate discussion in design teams and may hinder teacher learning. Research should, therefore, focus on how external priorities and practical concerns impact teachers' learning in collaborative design processes.

\section{Agency}

In collaborative design, teacher agency is shaped by the teacher's existing orientation towards the subject matter, pedagogy and technology related to a specific design task (Boschman et al. 2014) —or, in other words, a teacher's belief system. According to Korthagen and Kessels (1999) teacher's epistemic beliefs shape the conceptualisation of problems, especially in the case of creative activity, such as design. White (2000) related epistemic beliefs to teachers' curricular and instructional choices. These findings suggest that a teacher's belief system affects teacher design practice. Our cases provide indications that participation in collaborative design contributes to changes in teacher beliefs about pedagogy (USA) and about teacher collaboration and quality curriculum materials (Africa). However, more research is needed to understand how individual beliefs impact teacher learning in collaborative design and how we can identify situated contexts that will increase the chance for all teachers to create authentic and meaningful designs as they move beyond their original individual beliefs.

Equally important for teacher agency is the sense of ownership, as has also been demonstrated in the three cases of this study. Several studies investigated how different designer roles contribute to a sense of ownership and impact the planning and 
implementation of the designed artefact in education practice (Penuel et al. 2009; Cviko et al. 2014). Penuel et al. (2009) demonstrated that teachers in a co-designer or re-designer role adopted instructional planning practices as a result of the role assigned to them also after the professional development program had finished. Cviko et al. (2014) found that teachers embraced re- and co-designer roles, which resulted in better enactment of the designed artefact in instructional practice. These studies suggest that re- and co-design help teachers learn to better understand the innovation and provide them with competences in instructional planning and enactment.

\section{Cyclical nature of learning and change}

By using the IMPG model (Clarke and Hollingsworth 2002) the African cases offer some insights in how collaborative design contributes to learning and how learning from design is refined when the design is enacted in practice. The results of the studies of Penuel et al. (2009) and Cviko et al. (2014), suggest that teachers developed instructional planning competencies through design and enactment of curriculum innovations. Additional research is needed to better understand the mutual relationship of design and enactment for learning.

Team learning in collaborative design

Research at the team level concerning situatedness, agency and the cyclical nature of learning and change deals with understanding team learning though collaborative design.

\section{Situatedness}

As the African and Canada cases illustrate, the effects of design teams are also determined by the interactions within the team and of the team with its environment. Social network analysis offers a new lens and methodology to study collaboration in teams. Recent work of Penuel et al. (2012) explored the use of social network analysis to investigate direct and indirect impacts of professional development on teacher learning. We propose to apply this approach to study in-depth how collaborative (re-design) team affects team learning.

\section{Agency}

As the Canada case showed, collaborative design both transforms the individual and the group in a reciprocal process (Rogoff 1994). Research on team learning as a result of collaborative design is relatively scarce. The Canadian case portrays team learning as shared transformative agency, indicating that the design task (and the related innovation) is not only an individual asset, but becomes shared. From the perspective of teacher learning through collaborative design we advocate research on the impact of three factors and how they contribute to teacher learning in collaborative design processes. These factors are: (a) culture and social interaction (e.g. Wertsch 1991), (b) community (e.g. Bransford et al. 1999) and (c) cultural apprenticeship and guided participation (Rogoff 1990).

\section{Cyclical nature of learning and change}

Our cases do not reveal in-depth knowledge on how knowledge develops in design teams and how this affects team learning and team effectivity. In the frame of research on 
effective teams in corporate settings Mohammed et al. (2010) reviewed the literature on team mental models. Research on team mental models focuses on how shared understanding of the key elements of the task and the collaborative process affects teams performance. This approach might be promising in studying team learning in collaborative design, in particular, when attention is being paid to the team learning related to the cyclical nature of design work.

System learning in collaborative design

At the system level, the features situatedness, agency and the cyclical nature of learning and change concern the relationships with stakeholders other than teachers in collaborative design processes to provide structure, facilities and incentives for teacher learning.

\section{Situatedness}

Scalability concerns the conditions that need to be in place to scale collaborative design to large numbers of other settings (cf. phases 2 and 3 of Borko's (2004) research agenda for professional development arrangements). Scaling triggers the need for a better understanding of the situated nature of collaborative design processes. Not much research on scaling innovations is done, let alone scaling of collaborative design as a form of professional development. In this regard, the Canadian case described in this contribution is rather unique, although limited from the perspective of scale.

\section{Agency}

Sustainability involves: maintaining improvement over time, learning gains for everyone and not a few and availability of resources and opportunities to solve problems in a flexible way (Hargreaves and Fink 2000). At the system level, shared transformative agency is a relevant concept, as was shown in the Canadian case where shared transformative agency within and between schools and within and between university-school partnerships was important for sustainability of the RNS. In the African case an effort was made to investigate the sustainability of collaborative design as a professional development approach within institutions after the intervention had finished. Bakah et al. (2012b) went back to the study sites after the formal termination of the teacher design teams intervention and found that the concept of teacher design teams had sustained and expanded to other departments and for other curriculum-related problems involving other teachers. The study of Bakah et al. (2012b) was framed on theoretical notions provided by theories of change as stated by Coburn (2003). Coburn (2003) describes scaling of innovations as the result of a set of four interrelated dimensions: spread, depth, sustainability and shift in ownership. To study sustainability and shift in ownership social network analysis (see previous section) can also be a useful approach, as it can help to better understand how collaborative design teams are situated in the context of their school and other partnerships. This may contribute to a better understanding of system learning through collaborative design.

\section{Cyclical nature of learning and change}

Transferability relates to the frame of iterative learning through involvement in collaborative design processes. We know of only a few studies in this area pertaining to 
collaborative design in teams as a way of learning in pre-service teacher education (Agyei and Voogt 2014; Kafyulilo et al. 2013). These studies investigated the extent to which preservice teachers who had become beginning teachers at the moment of study used technology integration knowledge and skills that were learned through participation in a collaborative design arrangement during their pre-service teacher education. The studies used Baldwin and Ford's (1988) model of transfer of learning and were able to show that involvement in collaborative design accounted directly (Agyei and Voogt 2014) or indirectly (Kafyulio et al. 2013) for continuous use of the knowledge and skills learned in their respective practices. These studies also showed that school environment factors often hindered continuation of the use of these knowledge and skills in new settings.

\section{Conclusion}

This contribution focused on collaborative design as a form of professional development in the context of curriculum change. By using situated learning theory and activity theory, we identified situatedness, agency and the cyclical nature of learning and change as key features of learning in collaborative design processes. This was illustrated in three cases where collaborative design by teachers was applied. Key differences between cases are summarized in Table 1. This contribution resulted in a substantive research agenda to guide further research in teacher learning by collaborative design as a professional development strategy.

Open Access This article is distributed under the terms of the Creative Commons Attribution License which permits any use, distribution, and reproduction in any medium, provided the original author(s) and the source are credited.

\section{References}

Agyei, D., \& Voogt, J. (2014). Examining factors affecting beginning teachers' transfer of learning of ICTenhanced learning activities in their teaching practice. Australasian Journal of Educational Technology, 30(1), 92-105.

Allaire, S., Beaudoin, J., Breuleux, A., Hamel, C., Inchauspé, P., Laferrière, T., \& Turcotte, S. (2006). L'école éloignée en réseau. Rapport de recherche, phase II, CEFRIO, Québec. English summary retrieved from http://www.cefrio.qc.ca/media/uploader/SyntheseEERphase-2anglaisfinal.pdf.

Allaire, S., \& Lusignan, G. (2011). Enseigner et apprendre en réseau: collaborer entre écoles distantes à l'aide des TIC. Anjou: Éditions CEC.

Anto, A. G. (2013). Collaborative teacher professional development in Ethiopian higher education: The case of communicative language teaching (Doctoral dissertation. Enschede: University of Twente).

Anto, A. G., Coenders, F., \& Voogt, J. (2012). Assessing the current implementation of communicative language teaching of Ethiopian universities english language teachers. Staff and Educational Development International Journal, 16(1), 51-69.

Bakah, M. A. B. (2011). Collaborative course design to support implementation of e-learning by instructors (Doctoral dissertation. Enschede: University of Twente).

Bakah, M. A. B., Voogt, J. M., \& Pieters, J. M. (2012a). Professional development needs of polytechnic lecturers in a curriculum reform scenario. International Journal of Training and Development, 16(1), 67-76.

Bakah, M. A. B., Voogt, J. M., \& Pieters, J. M. (2012b). Advancing perspectives of sustainability and largescale implementation of design teams in Ghana's polytechnics: Issues and opportunities. International Journal of Educational Development, 32(6), 787-796.

Barab, S., Kling, R., \& Gray, J. H. (2004). Designing for virtual communities in the service of learning. New York, NY: Cambridge University Press. 
Bereiter, C., \& Scardamalia, M. (1993). Surpassing ourselves: An inquiry into the nature and implications of expertise. Chicago and La Salle: Open Court.

Borko, H. (2004). Professional development and teacher learning: Mapping the terrain. Educational Researcher, 33(8), 3-15.

Boschman, F., McKenney, S., \& Voogt, J. (2014). Understanding decision-making in teachers' curriculum design approaches. Educational Technology Research and Development, 62, 393-416.

Bowles, T., \& Hattie, J. (2013). Towards positive adaptive change: The association of three typologies of agency with motivational factors. Australian Psychologist, 48, 437-444.

Bransford, J., Brown, A. L., \& Cocking, R. R. (Eds.). (1999). How people learn: brain, mind, experience, and school. Washington, D.C.: National Academies Press.

Clandinin, J., \& Connelly, F. (1992). Teacher as curriculum maker. In P. Jackson (Ed.), Handbook of research on curriculum (pp. 363-401). New York: Macmillan.

Clarke, D., \& Hollingsworth, H. (2002). Elaborating a model of teacher professional growth. Teaching and Teacher Education, 18, 947-967.

Coburn, C. E. (2003). Rethinking scale: Moving beyond numbers to deep and lasting change. Educational Researcher, 32(6), 3-12.

Cordingley, P., Bell, M., Rundell, B., Evans, D. (2003). The impact of collaborative CPD on classroom teaching and learning. In Research evidence in education library. London: EPPI-Centre, Social Science Research Unit, Institute of Education, University of London.

Cordingley, P., Bell, M., Thomason, S., Firth, A. (2005). The impact of collaborative continuing professional development (CPD) on classroom teaching and learning. Review: How do collaborative and sustained CPD and sustained but not collaborative CPD affect teaching and learning? In: Research evidence in education library. London: EPPI-Centre, Social Science Research Unit, Institute of Education, University of London.

Cviko, A., McKenney, S., \& Voogt, J. (2014). Teacher roles in designing technology-rich learning activities for early literacy: A cross-case analysis. Computers \& Education, 72, 68-79.

Doyle, W., \& Ponder, G. A. (1978). The practicality ethic in teacher decision-making. Interchange, 8(3), $1-12$.

Elmore, R. F., \& Burney, D. (1999). Investing in teacher learning. In L. Darling-Hammond \& G. Sykes (Eds.), Teaching as the learning profession (pp. 236-291). San Francisco: Jossey-Bass.

Engeström, Y. (1987). Learning by expanding: An activity-theoretical approach to developmental research. Helsinki: Orienta-Konsultit.

Engeström, Y. (2006). Activity theory and expansive design. In S. Bagnara \& G. Crampton Smith (Eds.), Theories and practice in interaction design: Interaction design (pp. 3-25). New York: Lawrence Erlbaum.

Engeström, Y. (2011). From design experiments to formative interventions. Theory \& Psychology, 21(5), $598-628$.

Engeström, Y., \& Sannino, A. (2010). Studies of expansive learning: Foundations, findings and future challenges. Educational Research Review, 5(1), 1-24.

Engle, R. A., \& Conant, F. R. (2002). Guiding principles for fostering productive disciplinary engagement: Explaining an emergent argument in a community of learners classroom. Cognition and Instruction, 20(4), 399-483.

Fishman, B., Konstantopoulos, S., Kubitskey, B. W., Vath, R., Park, G., Johnson, H., \& Edelson, D. C. (2013). Comparing the impact of online and face-to-face professional development in the context of curriculum implementation. Journal of Teacher Education, 64(5), 426-438.

Garet, M. S., Porter, A. C., Desimone, L., Birman, B. F., \& Yoon, K. S. (2001). What makes professional development effective? Results from a national sample of teachers. American Educational Research Journal, 38, 915-945.

Greeno, J. G. (1997). On claims that answer the wrong questions. Educational Researcher, 26(1), 5-17. doi: $10.3102 / 0013189 \times 026001005$.

Greeno, J. G. (2011). A situative perspective on cognition and learning in interaction. In T. Koschmann (Ed.), Theories of learning and studies of instructional practice (Vol. 1, pp. 41-71). New York: Springer.

Greeno, J. G., \& Middle School Mathematics through Applications Project Group. (1998). The situativity of knowing, learning, and research. American Psychologist, 53(1), 5-26.

Handelzalts, A. (2009). Collaborative curriculum development in teacher design teams. Enschede: University of Twente.

Hargreaves, A., \& Fink, D. (2000). The three dimensions of reform. Educational Leadership, 57(7), 30-34.

Hickey, D. T., \& Itow, R. C. (2012) Participatory assessment for participatory teaching \& learning in school contexts. In E. Reilly \& I. Literat (Eds) Designing with teachers: Participatory approaches to 
professional development (pp. 78-88). USC Annenberg Innovation Lab. http://dmlcentral.net/ resources/5135.

Huizinga, T., Handelzalts, A., Nieveen, N., Voogt, J. (2014). Fostering teachers' design expertise in teacher design teams: Conducive design and support activities. The Curriculum Journal. doi:10.1080/ 09585176.2014.990395

Inchauspé, P., Laferrière, T., Breuleux, A., Hamel, C., Allaire, S., Turcotte, S. (2004). Remote Networked Schools: A Contribution to the Sustainability and Development of Small Village Schools. Quebec, Canada: CEFRIO. Retrieved from http://www.cefrio.qc.ca/media/uploader/Rapport-syntheseEERsmallvillageschools-anglais.pdf.

Ito, M., Guiterrez, K., Livingstone, S., Penuel, B., Rhodes, J., Salen, K., et al. (2013). Connected learning: An agenda for research and design. Irvine: Digital Media and Learning Hub.

Itow, R.C., \& Hickey, D. T., (2012). Design-based implementation research of spreadable educational practices within the Participatory Learning and Assessment Network (PLAnet). In J. van Aalst, K. Thompson, and M. J. Jacobson, and P. Reimann (Eds.), Proceedings of the 10th International Conference of the Learning Sciences: The future of learning.

Jenkins, H. (2009). Confronting the challenges of participatory culture: Media education for the 21st century. Boston: MIT Press.

Jonassen, D. H., \& Reeves, T. C. (1996). Learning with technology: Using computers as cognitive tools. In D. H. Jonassen (Ed.), Handbook of research for educational communications and technology (pp. 693-719). New York: Macmillan.

Kafyulilo, A. (2013). Collaborative design in teams to develop science and mathematics teachers' technology integration skills (Doctoral dissertation. Enschede: University of Twente).

Kafyulilo, A., Fisser, P., Voogt, J. (2013). Factors determining pre-service and in-service teachers' continuous use of technology after participation in professional development. Paper presented at ISATT, July 2-5, Ghent.

Kaptelinin, V. (2005). The object of activity: Making sense of the sense-maker. Mind, Culture, and Activity, 12(1), 4-18.

Koehler, M. J., \& Mishra, P. (2008). Introducing TPCK. In AACTE (Ed.), Handbook of technological pedagogical content knowledge (TPCK) for educators (pp. 3-29). New York: Routledge.

Korthagen, F. A. J., \& Kessels, J. W. M. (1999). Linking theory and practice: Changing the pedagogy of teacher education. Educational Researcher, 28(4), 4-17.

Laferrière, T., Allaire, S., Breuleux, A., Hamel, C., Turcotte, S., Gaudreault-Perron, J., Inchauspé, P., Beaudoin, J. (2008). L'école éloignée en réseau: L'apprentissage des élèves. Rapport de recherche, phase III, CEFRIO, Québec. Retrieved from http://www.eer.qc.ca/doc/2009/EER_rapport-synthese_ phase-3.pdf.

Laferrière, T., \& Breuleux, A. (2011). Collaborative Design (CODE) as a Teacher Professional Development Model in Francophone and Anglophone Quebec. In H. Spada, G. Stahl, N. Miyake, \& N. Law (Eds.), CSCL 2011 : Computer-supported collaborative learning. Connecting research to policy and practice. Conference proceedings, vol. 3 (pp. 1178-1181). International Society of the Learning Sciences \& Center for Information Technology in Education, University of Hong Kong.

Latour, B. (2008). A cautious Prometheus? A few steps toward a philosophy of design. In J. Glynne, F. Hackney, \& V. Minton (Eds.), Networks of design (pp. 2-10). Boca Raton: BrownWalker Press.

Lave, J., \& Wenger, E. (1991). Situated learning: Legitimate peripheral participation. Cambridge: Cambridge University Press.

Martin, S. D., Snow, J. L., \& Franklin Torrez, C. A. (2011). Navigating the terrain of third space: Tensions with/in relationships in school-university partnerships. Journal of Teacher Education, 62(3), 299-311. doi:10.1177/0022487110396096.

McKenney, S. E., \& Reeves, T. C. (2012). Conducting educational design research. London: Routledge.

Miettinen, R. (2013). Innovation, human capabilities, and democracy: Towards an enabling welfare state. Oxford: Oxford University Press.

Mohammed, S., Ferzandi, L., \& Hamilton, K. (2010). Metaphor no more: A 15-year review of the team mental model construct. Journal of Management, 36, 876-910.

Ormel, B., Pareja Roblin, N. D., McKenney, S. E., Voogt, J. M., \& Pieters, J. M. (2012). Research-practice interactions as reported in recent design studies: Still promising, still hazy. Educational Technology Research and Development, 60(6), 967-986.

Parke, H. M., \& Coble, C. R. (1997). Teachers designing curriculum as professional development: A model for transformational science teaching. Journal of Research in Science Teaching, 34(8), 773-789.

Penuel, W. R., Fishman, B. J., Haugan Cheng, B., \& Sabelli, N. (2011). Organizing research and development at the intersection of learning, implementation, and design. Educational Researcher, 40(7), $331-337$. 
Penuel, W. R., Fishman, B. J., Yamaguchi, R., \& Gallagher, L. P. (2007). What makes professional development effective? Strategies that foster curriculum implementation. American Educational Research Journal, 44(4), 921-958.

Penuel, W. R., McWilliams, H., McAuliffe, C., Benbow, A. E., Mably, C., \& Hayden, M. M. (2009). Teaching for understanding in earth science: Comparing impacts on planning and instruction in three professional development designs for middle school science teachers. Journal of Science Teacher Education, 20, 415-436.

Penuel, W. R., Sun, M., Frank, K. A., \& Galaggher, H. A. (2012). Using social network analysis to study how collegial interactions can augment teacher learning from external professional development. American Journal of Education, 119, 103-136.

Pieters, J., \& Voogt, J. (2008). Curriculum, docent en innovative [curriculum, teacher and innovation], research program of the department curriculum design and educational innovation. Enschede: University of Twente.

Putnam, R. T., \& Borko, H. (2000). What do new views of knowledge and thinking have to say about research on teacher learning? Educational Researcher, 29(1), 4-15.

Rogoff, B. (1990). Apprenticeship in thinking: Cognitive development in social context. New York: Oxford University Press.

Rogoff, B. (1994). Developing understanding of the idea of communities of learners. Mind, Culture and Activity, 1, 209-222.

Sannino, A., \& Sutter, B. (2011). Cultural-historical activity theory and interventionist methodology: Classical legacy and contemporary developments. Theory \& Psychology, 21(5), 557-570. doi:10.1177/ 0959354311414969.

Scardamalia, M., \& Bereiter, C. (1994). Computer support for knowledge-building communities. The Journal of the Learning Sciences, 3(3), 265-283.

Schön, D. A. (1983). The reflective practitioner: How professionals think in action. New York: Basic Books.

Van den Akker, J., Gravemeijer, K., McKenney, S., \& Nieveen, N. (Eds.). (2006). Educational design research. London: Routledge.

Vanninen, R. (2013). Generating transformative agency in a split community of greenhouse growers. Presentation at the Summer School in Activity Theory and Formative Intervention.

Velthuis, C., Fisser, P., \& Pieters, J. (2014). Collaborative curriculum design to increase science teaching self-efficacy: A case study. Journal of Educational Research,. doi:10.1080/00220671.2013.878299.

Vescio, V., Ross, D., \& Adams, A. (2008). A review of research on the impact of professional learning communities on teaching practice and student learning. Teaching and Teacher Education, 24(1), 80-91.

Virkkunen, J., \& Newnham, D. S. (2013). The change laboratory: A tool for collaborative development of work and education. Rotterdam: Sense Publishers.

Voogt, J., Westbroek, H., Handelzalts, A., Walraven, A., Mckenney, S., Pieters, J., \& De Vries, B. (2011). Teacher learning in collaborative curriculum design. Teaching and Teacher Education, 27(8), 1235-1244.

Vygotsky, L. S. (1987). The collected works of L. S. Vygotsky. New York: Plenum.

Wertsch, J. (1991). Voices of the mind: A sociocultural approach to mediated action. Cambridge: Harvard University Press.

White, B. C. (2000). Pre-service teachers' epistemology viewed through perspectives on problematic classroom situations. Journal of Education for Teaching, 26, 279-305. 